\title{
Attitude to multiculturality at school scale: validation and psychometric properties on a Chilean sample
}

\author{
María José Mera Lemp로 Gonzalo Martínez-Zelaya², Marian Bilbao², \\ Roxana Zuleta ${ }^{4}$, Amanda Garrido 5 \\ Universidad Alberto Hurtado ${ }^{1,3}$, Universidad de Viña del Mar ${ }^{2}$, \\ Universidad Andrés Bello ${ }^{4,5}$
}

\begin{abstract}
The increasing number of immigrant students on the Chilean educational system stresses the importance of study teachers' attitudes to multiculturality in schools settings. Nevertheless, there is a lack of adequate measurement instruments to apply on Chilean population. The aim of this work was to validate the Attitude to Multiculturality at School Scale (León del Barco et al., 2007) on a Chilean sample, composed by $\mathrm{N}=160$ teachers. Confirmatory factor analysis showed that the unifactorial model had the best fit to the data. Correlation analysis revealed significant relations between attitude to multiculturality at school, perceived out-group threat and prejudice. Linear regression analysis showed that perceived threat and prejudice explained $42 \%$ of the attitude to multiculturality at school variability, supporting criterion validity.
\end{abstract}

Keywords: attitudes; multiculturality; school; immigrants; teachers

Escala de actitud hacia la multiculturalidad en la escuela: validación y propiedades psicométricas en una muestra chilena.

1 PhD in Social Psychology, Universidad del País Vasco. CONICYT/ FONDECYT Postdoctoral Researcher at Facultad de Psicología, Universidad Alberto Hurtado, Chile. Mailing address: Facultad de Psicología, Universidad 2. Alberto Hurtado. Almirante Barroso, 10, Santiago de Chile. E-mail: mmera@uahurtado.cl

2 PhD in Social Psychology, Universidad del País Vasco. Professor at Escuela de Ciencias Jurídicas y Sociales, Universidad Viña del Mar Mailing address: Escuela de Ciencias Jurídicas y Sociales, Universidad Vińa del Mar. Los Fresnos 91, Miraflores, Viña del Mar. E-mail: gonzalo.martinez@uvm.cl

3 PhD in Social Psychology, Universidad del País Vasco. Professor at at Facultad de Psicología, Universidad Alberto Hurtado, Chile. Mailing address: Facultad de Psicología, Universidad Alberto Hurtado. Almirante Barroso, 10, Santiago de Chile. E-mail: maria.bilbao@uahurtado.cl

4 Master in Social Work and Social Policy, Universidad de Concepción. Professor at Facultad de Educación y Ciencias Sociales, Universidad Andres Bello. Mailing address: Facultad de Educación y Ciencias Sociales, Universidad Andres Bello. Autopista Concepción-Talcahuano 7100, Concepción, Chile. E-mail: roxana.zuleta@unab.cl

5 Master in Clinical Psychology. Professor at Facultad de Educación y Ciencias Sociales, Universidad Andres Bello. Mailing addres: Facultad de Educación y Ciencias Sociales, Universidad Andres Bello. Autopista Concepción-Talcahuano 7100, Concepción, Chile. E-mail: amanda.garrido@outlook.cl 
Aunque el aumento del alumnado inmigrante en Chile subraya la importancia de estudiar actitudes de los docentes hacia la multiculturalidad, existe un déficit de instrumentos de medida para ser aplicados a la población local. El objetivo de este estudio es validar la Escala de Actitudes hacia la Multiculturalidad en la Escuela (León del Barco et al., 2007) en una muestra compuesta por $\mathrm{N}=160$ profesores chilenos. Se estableció que el modelo unifactorial presenta el mejor ajuste a los datos, y se determinó la existencia de relaciones significativas entre la actitud hacia la multiculturalidad, la amenaza exogrupal percibida y el prejuicio. Los análisis de regresión lineal seńalan que la amenaza exogrupal percibida y el prejuicio, explican el $42 \%$ de la variabilidad de la actitud hacia la multiculturalidad, apoyando la validez de criterio de la escala.

Palabras clave: actitudes; multiculturalidad; escuela; inmigrantes; profesores

Escala de atitude face á multiculturalidade na escola: validaçáo e propriedades psicométricas numa amostra chilena

$\mathrm{O}$ incremento dos estudantes imigrantes no sistema educativo chileno enfatiza a importância de pesquisar as atitudes dos docentes face á multiculturalidade em contextos escolares. Porém, existe um déficit de instrumentos de medição a serem aplicados à população local. O objetivo desta pesquisa foi validar a Escala de Atitude face á Multiculturalidade na Escola (León del Barco et al., 2007), numa amostra composta por $\mathrm{N}=160$ professores chilenos.. O modelo unifatorial apresenta o melhor ajuste aos dados. Os resultados confirmam a existência de relaçôes significativas entre a atitude face á multiculturalidade, a percepção de ameaça exogrupal e o preconceito. As análises de regressão linear indicam que a ameaça exogrupal e o preconceito explicam $42 \%$ da variabilidade da atitude face á multiculturalidade, apoiando a validade de critério da escala.

Palavras chave: atitudes, multiculturalidade, escola, imigrantes, professores.

Echelle d'attitude envers le multiculturalisme à l'école: validation et propriétés psychométriques dans un échantillon chilien.

L'augmentation des étudiants immigrants dans le système éducatif chilien souligne l'importance d'études l'attitude des professeurs à l'égard de la multiculturalité en milieu scolaire. Néanmoins, il n'existe pas d'instruments de mesure adéquats à appliquer à la population chilienne. Le but de ce travail était de valider l'échelle d'attitude envers la multiculturalité à l'école (León del Barco et al., 2007) sur un échantillon chilien composé de $\mathrm{N}=160$ enseignants. Une analyse factorielle confirmatoire a montré que le modèle uni factoriel correspondait le mieux aux données. L’analyse de corrélation a révélé des relations significatives entre l'attitude envers la multiculturalité à l'école, la menace de l'exogroupe et le préjugé. Une analyse de régression linéaire a montré que la menace et le préjugé perçus expliquaient $42 \%$ de l'attitude vis-à-vis de la variabilité multiculturelle à l'école, étayant ainsi la validité du critère.

Mots-clé: attitude, multiculturalité, école, immigrants, professeurs. 
During the last two decades, Chile's migratory profile has shown significant changes related to a sustained growth of its immigrant population, and the increasing number of Latin-Americans newcomers, who represent $90.96 \%$ of the foreign inhabitants of the country (Instituto Nacional de Estadísticas, 2020).

One of the most important features of this new migration pattern is the increase of the school age children and adolescents segment, which corresponds to $15 \%$ of immigrant population (Instituto Nacional de Estadísticas, 2018). In fact, the number of foreign students on Chilean educational system was doubled between 2015 and 2017 , representing $2.2 \%$ of the total student body. Immigrant students are mainly concentrated on primary education (64\%), while $25 \%$ is enrolled on secondary schools, and $11 \%$ attend to pre-school education. It is also relevant to note that immigrant students tend to study mostly on public schools financed by the State but administered by local municipalities (58\%) than Chilean students (36\%), who are principally enrolled on subsidized schools (55\%), financed by the State but administrated by private organizations. In both cases, only the $9 \%$ of the students attend to private centers (Ministerio de Educación de Chile, 2018). These data suggest an educational segregation tendency through which immigrant students are acceding to the schools with lowers socioeconomic profiles (Joiko \& Vázquez, 2016),

Immigrant children and adolescents' schooling is an emerging research topic on the local context, and there is growing evidence indicating intergroup conflict dynamics between Chilean and LatinAmerican students, as well as between them, their families and teachers. These studies have reported, mostly through qualitative designs, the existence of prejudices (Cárdenas, 2006; Navas et al., 2009; Navas \& Sánchez, 2010; Salas et al., 2017), discrimination (de la Torre Díaz, 2011; Hein, 2012; Hernández, 2016), exclusion (Pavez, 2012) and 
racialization processes (Riedemann \& Stefoni, 2015; Tijoux, 2013), which tend to be naturalized on school settings, and might have an important impact on teaching-learning interactions and also on school climate.

This new multicultural scenario is challenging for teaching staffs, who are key actors on cultural diversity management at schools (Gutentag et al., 2017). Teachers' behaviors and attitudes toward multiculturalism have impact on students' intergroup relations by influencing native pupils' perceptions about their foreign peers (Horenczyk \& Tatar, 2002). Likewise, educators' beliefs, expectations and valuations about cultural minority students' schooling processes are critical to their well-being and to their academic outcomes (Carter, 2006; Kao \& Thompson, 2003; Pajares, 2007; Tyler et al., 2006; Verkuyten \& Thijs, 2002; Wong et al., 2003).

In Chile, immigrants' arrival to schools has been faced by educators on a brief period of time, with scarce preparation and lack of resources. Teachers have been educated on a monocultural system and prepared to teach to a homogeneous student body, through a professional training process that rarely involves the development of knowledge and skills related to multicultural education (Barrios-Valenzuela \& Palou-Julián, 2014).

Furthermore, even though teachers may have access to establish close relations with immigrant families and get to know their sociocultural realities, some studies have shown that their perceptions of cultural diversity at schools tend to reflect general population attitudes to immigration on the larger society (Horenczyk \& Tatar, 2002; Siqués et al., 2009; Vecina, 2006). Due to their position as members of the majoritarian society, teachers' social identities might be threatened by immigrants groups (Tajfel \& Turner, 1979), triggering ambiguous or negative reactions towards them.

Prejudice has been defined as a negative cognitive or affective response towards groups and their members, and it has a relevant role on the creation or preservation of intergroup hierarchical relations (Dovidio et al., 2010; Yzerbyt \& Demoulin, 2010). As well as per- 
ceptions, judgments, beliefs and stereotypes about a group, emotions are an important component of prejudice (Tropp \& Pettigrew, 2005), which are determinated by the effects of social interactions on status and power (Kemper, 1984). Moreover, these feelings contribute to intergroup boundaries' delimitation and maintenance, by reinforcing group identities or preventing the contact between groups (Aberson, 2015; Keltner \& Haidt, 1999). Thus, affective prejudice might leads to negative attitudes and behaviors toward cultural diversity (Aberson, 2015; Navas \& Rojas, 2010), and it seems to be critical for educators whom emotions have impact on students' affective experiences at school (Frenzel et al., 2017; Hagenauer et al., 2015).

Besides, several studies have shown that host societies members attitudes to multiculturalism, are negative related to the degree in which newcomers are perceived as competitors for material or symbolic resources (Sirlopú \& Van Oudenhoven, 2013; Spencer-Rodgers \& McGovern, 2002; Stephan et al., 2005; Vedder et al., 2016; Velasco et al., 2008; Ward \& Masgoret, 2008). Realistic threat consists on the idea that immigrant groups represent a risk for natives' access to welfare, job market or housing, and it can be perceived even when host society members' individual interests are not in conflict.

Symbolic threat, in turn, entails the belief that immigrant groups systems of values and norms are incongruent with host society dominant culture, putting cultural homogeneity at risk (Stephan et al., 2005), which may be specially sensible for teaching settings. Threat perceptions lead groups to develop strategies to protect their own material interests and culture, diminishing their acceptance of diversity and avoiding intergroup contact (Bourhis et al., 2009; Florack et al., 2003; González et al., 2010; Montreuil et al., 2004), by their association to prejudice.

In the case of Chilean teachers, there is scarce evidence of their perceptions about multiculturality at school. A qualitative study conducted by Jimenez \& Fardella (2015) found interpretative repertories which varied from cultural diversity invisibilization, to the perception of cultural diversity as a factor that hinders schooling processes' normal 
development, preferring immigrant students' segregation or assimilation to the mainstream culture. A third kind of approach consisted in the idea of multiculturality at school as a normal consequence of migratory processes, which doesn't requires teachers adaptation but immigrant students individual efforts to fit in to the new context (Jiménez \& Fardella, 2015).

In other research (Salas et al., 2017), conducted by a mixed method design, qualitative results showed that teachers believed that foreign pupils' enrollment had several negative consequences to schools, such as the loss of prestige, Chilean families "scape" from their schools, and the worsening of education quality. Teachers on this study also tended to perceive that immigrant students have fewer learning capabilities than natives because of their cultural origin. As a consequence, they coincided on segregate them on separated groups inside the classrooms as a strategy to avoid Chilean pupils' academic backwardness.

These findings seem to be consistent with results from studies with general Chilean population, which have aware about the construction of negative attitudes, low social recognition, racism and discriminative behaviors towards Latin-American immigrants (Mera et al., 2017; Thayer et al., 2013; Tijoux \& Palominos, 2015; Valenzuela et al., 2014; Sirlopú \& Van Oudenhoven, 2013).

Nevertheless, due to the importance of teachers' role on immigrant students' sociocultural integration, it is urgent to increase local knowledge production about their particular perceptions of school as a multicultural scenario, which poses the need of counting with adequate measurement instruments. Recently, Salas et al. (2017) made an interesting contribution by applying the Attitude to Multiculturality at School Scale (León del Barco et al., 2007), originally constructed with a Spanish sample, on 44 Chilean teachers, which results were analyzed and complemented with qualitative data. This work aims to be a new advance on Salas' work, by validating and studying the psychometric properties of the Attitude to Multiculturality at School Scale (León del Barco et al., 2007) on a Chilean teachers sample. 


\section{Method}

\section{Participants}

The sample was composed by $N=160$ Chilean teachers, with ages between 23 and 65 years $(M=40.40 ; S D=11.35) .70 .6 \%$ were women and $29.4 \%$ had pedagogy degree studies, while $35.4 \%$ had postgraduate studies. $57.7 \%$ of the participants were primary education teachers, and $42.3 \%$ were teachers on secondary education.

\section{Variables and Instruments}

Attitude to Multiculturality at School: Attitude to Multiculturality at School Scale (León del Barco et al., 2007) was applied. This instrument was constructed with a Spanish sample, and it is composed by 8 items on a 5-point Likert scale (Completely disagree=1, Completely agree $=5$ ). Items are grouped on 3 dimensions: positive attitudes towards multiculturality at school (items 1,2 and 3), negative attitudes towards multiculturality at school (items 4, 5, 7 and 8), and immigrant students' aptitude versus natives (item 6). In the original study of León del Barco et al. (2007), the alphas reported were of .88 for the dimension negative attitudes towards multiculturality at school, and .83 for positive attitudes towards multiculturality at school dimension, while the general internal consistency of the instrument was $\alpha=.81$.

Threat perception: To assess perceived threat we used a scale based on the Basque Observatory of Immigration Questionnaire (Aierdi et al., 2004), previously adapted to the Chilean context (Mera et al., 2017). It consists on 7 items with a 5 point Likert-scale ( $1=$ totally disagree; $5=$ totally agree), where 6 items evaluated realistic threat, while 1 item assessed symbolic threat $(\alpha($ Cronbach $)=.93 ; \omega(\mathrm{McDonald})=.93)$.

Prejudice: Navas \& Rojas (2010) Affective Prejudice Scale was applied, which consists on 11 items: 4 items including traditional negative emotions (fear, hate, disregard, irritation), 4 items including subtle negative emotions (indifference, distrust, insecurity, discomfort), and 3 items comprising positive emotions (respect, admiration, sympathy). 
Participants had to indicate, using a 5 point Likert-scale ( $1=$ nothing, $5=\mathrm{a}$ lot), the degree in which they had felt each of these emotions towards Latin-American immigrants. In this study, the disregard's item presented a low correlation with the total scale, thus, we opted to not include it on data analysis $(\alpha($ Cronbach $)=.87 ; \omega($ McDonald $)=.87)$.

\section{Procedure}

Participants' selection was conducted using a convenience sampling, according to schools availability and teachers' voluntary participation. Eight schools agreed to participate in the study. All participants were informed about the goals and confidentiality conditions of the research, in order to comply with ethical and legal frameworks of informed consent. Questionnaire administration was done individually on schools, and had an average length of 20 minutes.

\section{Data Analysis}

The dimensional structure of the original model proposed by León del Barco et al. (2007), which is composed by 8 items, was examined through a confirmatory factor analysis (CFA). Different indices were used to evaluate the goodness-of-fit of the model: a) Chi-square, which must be not significant. Due to its sensitivity to the sample size, we also used b) Chi-square divided by degrees of freedom ( $\left.\chi^{2} / d f\right)$, accepting values lower than 5 (Jöreskog \& Sörbom, 1996); (c) Comparative Fit Index (CFI); (d) Tucker-Lewis Index (TLI); and (e) Bentler-Bonett Normed Fit Index (NFI). For those indices, values equal and over .90 are considered acceptable, while values equal or over .95 indicate a good fit of the model. We also used (f) Parsimony normed fit index (PNFI), at which values above .50 are considered adequate; (g) Akaike's information criterion $(A I C)$, which is a comparative measure of fit between different models. Lower values indicate a better fit, thus, the model with the lowest $A I C$ is the best fitting mode; (h) Root Mean Square Error of Approximation (RMSEA) at which values lower than .08 are accepted; and (i) Standardized Root Mean Square Residual (SRMR), where values 
lower than.05 indicates an adequate fit (Bentler \& Bonett, 1980; Hu \& Bentler, 1999; Yu, 2002). In order to study the criterion validity of the Attitude to Multiculturality at School Scale (León del Barco et al., 2007), Pearson's correlations analysis were calculated. Data analyses were conducted with the statistical software JASP V.9.9.

\section{Results}

\section{Structural Validity}

The original model (figure 1), which consists on 8 items and 3 dimensions (figure 1), was tested. The dimension "positive attitudes to multiculturality at school" is composed by items 1, 2 and 3, dimension "negative attitudes to multiculturality at school" includes the inverse items 4, 5, 7 and 8, and the third dimension, 'immigrant students' aptitude versus natives", is composed only by the inverse item 6 (León del Barco et al., 2007). This model didn't present adequate fit indices $\left(\left(\chi_{(17, \mathrm{~N}=160)}^{2}=45.525, p .<.001 ; \chi^{2} / \mathrm{gl}=2.678 ; C F I=.948 ; T L I=.914 ;\right.\right.$ $N F I=.921 ; P N F I=.559 ; S R M R=.046 ; R M S E A=.102(90 \% C I$ $[.067, .139]))$, as can be seen on table 1 .

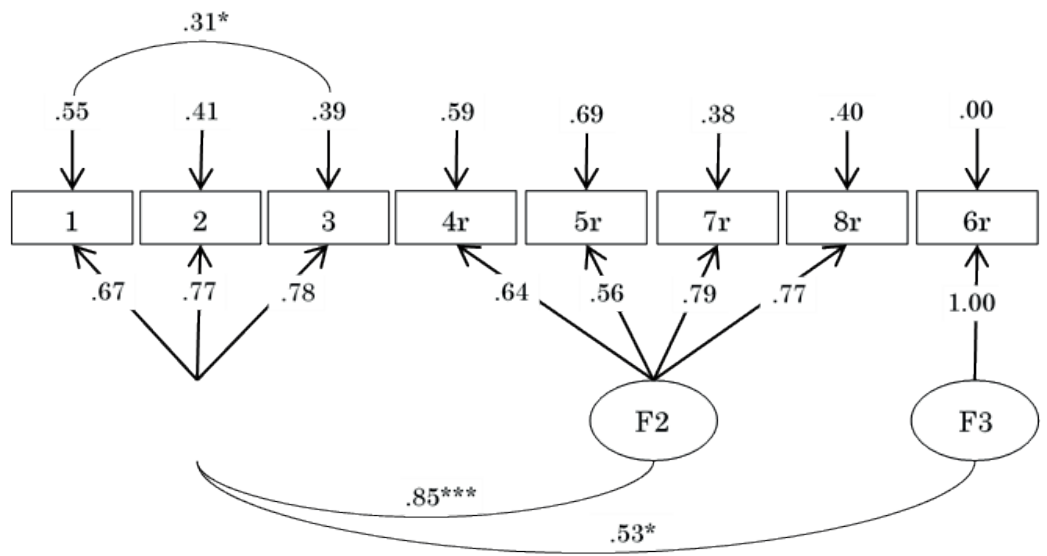

Figure 1. Original Trifactorial Model (León del Barco et al., 2007) 
Due to the inadequate fit of the original model, a bifactorial model was tested. The item which composed dimension 3 on the original model was included on dimension 2 , affecting the goodness-of-fit of the model, with unacceptable results on the different indices ( $(\chi 2)(17$, $N=160)=50.476, p .<.001 ; \chi 2 / g l=2.985 ; C F I=.939 ; T L I=.899$; $N F I=.912 ; P N F I=.554 ; S R M R=.051 ; R M S E A=.111(90 \% C I$ $[.076, .147]))$.

\section{Table 1}

Fit indices: Confirmatory Factorial Analysis

\begin{tabular}{llllllllllllll}
\hline \multicolumn{1}{c}{$\begin{array}{c}\mathrm{N}^{\circ} \\
\text { items }\end{array}$} & $\chi^{2}$ & $d / f$ & $\chi^{2 /} \mathrm{df}$ & $C F I$ & TLI & NFI & PNFI & AIC & SRMR & RMSEA & $\begin{array}{c}90 \% \text { CI } \\
\text { RMSEA }\end{array}$ \\
\hline Model 1 & 8 & 45.525 & 17 & 2.678 & .948 & .914 & .921 & .559 & 2257.935 & .046 & .102 & {$[.067-.139]$} \\
Model 2 & 8 & 50.476 & 17 & 2.985 & .939 & .899 & .912 & .554 & 2262.886 & .051 & .111 & {$[.076-.147]$} \\
Model 3 & 8 & 27.079 & 15 & 1.805 & .978 & .959 & .953 & .511 & 2243.489 & .038 & .071 & {$[.023-.113]$} \\
\hline
\end{tabular}

Consequently, a unifactorial solution was tested (figure 2 ). The third model presented satisfactory levels of goodness-of-fit ( $(\chi 2)(15$, $N=160)=27.079, p .=.028 ; \chi 2 / g l=1.805 ; C F I=.978 ; T L I=.959 ; N F I$ $=.953 ;$ PNFI $=.511 ;$ SRMR $=.038 ;$ RMSEA $=.071(90 \%$ CI [.023, $.113]))$. Scale's reliability $(\alpha($ Cronbach $)=.865 ; \omega(\mathrm{McDonald})=.876)$, assures its capability to differentiate between individuals who present a high attitude to multiculturality at school from those who show a low attitude to multiculturality at school. Table 2 shows descriptive data and reliability indices for each of the items. 


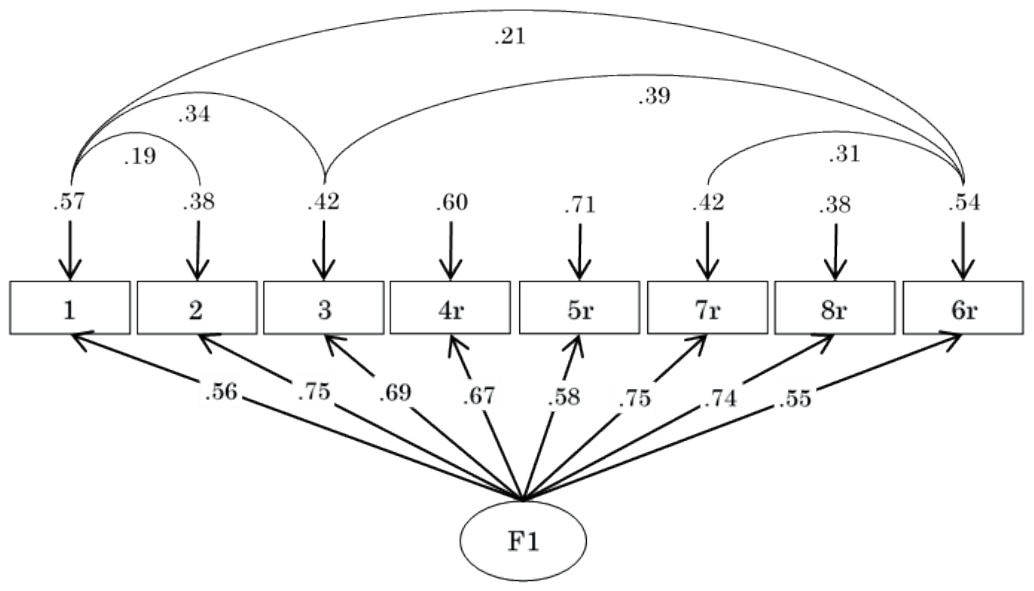

Figure 2. Unifactorial Model.

\section{Table 2}

Descriptive statistics and items' reliability

If the item is discarded

Items

$M \quad S D$

Item-Test correlation

McDonald $\omega$ Cronbach $\alpha$

1. A multicultural school would be good

$4.200 \quad .867$

.602

.864

.852

2. Every immigrant student have right to

education

3. Ethnic diversity at schools supposes a positive $4.475 \quad 760$ and enriching experience

4. Immigrant students' presence at a school has a negative impact on 
If the item is discarded

Items

$M \quad S D$

Item-Test correlation

McDonald $\omega$ Cronbach $\alpha$

5. Immigrant students' presence has a negative impact on school's

$\begin{array}{llll}4.737 & .649 & .477 & .875\end{array}$

.863

prestige..

6. Immigrant students are worse prepared than $4.206 \quad 946$ .606 .864 .855 natives students.

7- Immigrant students' presence at a school difficult development of $4.662 \quad .603$ .681 .856 .844 activities in the classroom

8. To have immigrant students is a serious $4.719 \quad 606$ .665 .858 .846 problem for schools

\section{Criterion validity}

The literature review, previously presented on this paper, strongly suggests that attitudes to multiculturality at school are related to teachers prejudices towards immigrants, and also to the degree in which they perceived them as threatening both on realistic and symbolic terms. In order to study the instrument criterion validity, correlation analyses between attitude to multiculturality at school, prejudice and perceived threat were performed.

Results showed high negative significant relations between the attitude to multiculturality at school and perceived threat $(r=-.60$; $p<.001)$, and also among attitudes to multiculturality school and prejudice $(r=-.61 ; p<.001)$. Thus, positive attitude to multiculturality at school was associated with low threat perception and low prejudice.

A two stage hierarchical multiple regression analysis was also conducted, with attitude to multiculturality at school as the dependent variable. Results revealed that at stage one, perceived out-group threat contributed significantly to the regression model $(F(1,159)=89,175$, 
$p<.001$ ) and accounted for $36 \%$ of the variation of the attitude to multiculturality at school. Affective prejudice was introduced at stage two, explaining an additional $7 \%$ of the attitude to multiculturality at school variance $(\mathrm{F}(2,159)=58.836, p<.001)$. Together, these two variables explained a $42 \%$ of the variability of participants' attitude to multiculturality at school.

\section{Table 3}

Multiple regression analysis predicting Attitude to Multiculturality at School

\begin{tabular}{lllllll}
\hline & \multicolumn{3}{c}{ Stage 1 } & \multicolumn{3}{c}{ Stage 2 } \\
& $B$ & SE $B$ & $\beta$ & B & SE B & $\beta$ \\
\hline Perceived Threat & -.32 & .03 & $-.60^{* * *}$ & -.18 & .05 & $-.34^{* * *}$ \\
Affective Prejudice & & & & -.31 & .07 & $-.37^{* * *}$ \\
& & & & & \\
& & & & & \\
$\mathrm{R}^{2}$ & .36 & & & & \\
$\mathrm{~F}$ & $89,17^{* * *}$ & & .07 & \\
$\Delta R 2$ & & & & & \\
$\Delta F$ & & & & & \\
\hline
\end{tabular}

Note. ${ }^{*} p<.05,{ }^{* *} p<.01,{ }^{* * *} p<.001$

\section{Discussion}

The aim of this work was to validate the Attitude to Multiculturality at School Scale (León del Barco et al., 2007) on a Chilean sample. Through a confirmatory factor analysis, we tested different structural models of the original instrument, confirming that the unifactorial model had the best fit to the data, and the internal consistency estimators presented adequate values. 
Also, correlational analysis showed that consistently with precedents studies, the attitude to multiculturality at school presented high negative significant relations with threat perception (Sirlopú \& Van Oudenhoven, 2013; Spencer-Rodgers \& McGovern, 2002; Stephan et al., 2005) and prejudice (Vedder et al., 2016; Velasco et al., 2008; Ward \& Masgoret, 2008). Moreover, the hierarchical regression analysis revealed that threat perception together with prejudice explained a $42 \%$ of the attitude to multiculturality at school variability, supporting the scale criterion validity.

It is relevant to note that the convenience sampling and sample size utilized in this study might represent important limitations which should be addressed in future researches with a more representative population of teachers. Nevertheless, we stress the importance of counting with an instrument which can be useful to detect teachers' attitudes to cultural diversity at school, and further, to improve our knowledge about intergroup relations impact on immigrant students schooling processes, by identifying variables which can be key to psychosocial and educational intervention. Future research might also consider teachers' acculturation attitudes toward immigrant students, and other important specific aspects such as their culturally responsive teaching skills (Gutentag et al., 2017). A deeper knowledge about these issues could contribute to the design of teachers training programs, which could improve their capabilities to cope with the challenges of cultural diversity, promoting positive intergroup relations at school.

We expect that this unifactorial version of the instrument could encourage scholars on this field to consider teachers' perspectives on multicultural schools settings, especially in contexts where diversity management is a new and challenging task, such as in the Chilean case.

\section{Acknowledgements}

This research was supported by CONICYT/FONDECYT Postdoctoral fellowship $\mathrm{N}^{\circ} 3180774$, and by the Laureate Center for Youth Studies at Universidad Andres Bello. 


\section{References}

Aberson, C. L. (2015). Positive intergroup contact, negative intergroup contact, and threat as predictors of cognitive and affective dimensions of prejudice. Group Processes \& Intergroup Relations, 18(6), 743-760. https://doi.org/10.1177/1368430214556699

Aierdi, X., Álvarez, I., Bonelli, L., Garaizabal,C., \& Wagman, D. (2004). Inmigración. Nuestros miedos e inseguridades. San Sebastián: Tercera Prensa.

Barrios-Valenzuela, A. \& Palou-Julián, B. (2014). Educación intercultural en Chile: la integración del alumnado extranjero en el sistema escolar. Revista Educación y Educadores, 17(3), 405-426. https://doi.org/10.5294/edu.2014.17.3.1

Bourhis, R., Barrette, G., El-Geledi, S., \& Schmidt, R. (2009). Acculturation orientations and social relations between immigrant and host community members in California. Journal of Cross-Cultural Psychology, 40(3), 443-467 https://doi. org/10.1177/0022022108330988

Cárdenas, M. (2006). Y verás cómo quieren en Chile: Un estudio sobre el prejuicio hacia los inmigrantes bolivianos por parte de jóvenes chilenos. Última Década, 24, 103-129. https://doi.org/10.4067/ S0718-22362006000100006

Carter, P. (2006). Straddling Boundaries: Identity, Culture, and School. Sociology of Education, 79(3), 304-328. https://doi. org/10.1177/003804070607900402

De la Torre Díaz, P. (2011). La migración vivenciada en el espacio escolar: la experiencia de alumnado extranjero en una escuela pública de Santiago. Paulo Freire. Revista de Pedagogía Crítica, 10(9), 113-126. https://doi.org/10.25074/07195532.9.443

Dovidio, J.F., Hewstone, M., Glick, P., \& Esses, V.M. (2010)Prejudice, Stereotyping and Discrimination: Theoretical and Empirical Overview. In The SAGE Handbook of Prejudice, Stereotyping and Discrimination. https://doi.org/10.4135/9781446200919.n1 
Florack, A., Piontkowski, U., Rohmann, A., Balzer, J., \& Perzig, S. (2003). Perceived intergroup threat and attitudes of host community members towards immigrants acculturation. Journal of Social Psychology, 143, 633-648. https://doi. org/10.1080/00224540309598468

Frenzel, A. C., Becker-Kurz, B., Pekrun, R., Goetz, T., \& Lüdtke, O. (2017). Emotion transmission in the classroom revisited: A reciprocal effects model of teacher and student enjoyment. Journal of Educational Psychology, 110 (5), 628-639. https://doi. org/10.1037/edu0000228

González, R., Sirlopú, D. \& Kessler, T. (2010). Prejudice among Peruvians and Chileans as a Function of Identity, Intergroup Contact, Acculturation Preferences, and Intergroup Emotions. Journal of Social Issues, 66(4), 803-824. https://doi. org/10.1111/j.1540-4560.2010.01676.x

Gutentag, T., Horenczyk, G., \& Tatar, M. (2017). Teachers' approaches toward cultural diversity predict diversity-related burnout and self-efficacy. Journal of Teacher Education, 1-12. https://doi. org/10.1177/0022487117714244

Hagenauer, G., Hascher, T., \& Volet, S. E. (2015). Teacher emotions in the classroom: associations with students' engagement, classroom discipline and the interpersonal teacher-student relationship. European Journal of Psychology of Education, 30(4), 385-403. https://doi.org/10.1007/s10212-015-0250-0

Hein, K. (2012). Migración y transición: hijos de inmigrantes de origen latinoamericano en su transición de la escuela al trabajo en Chile. Si Somos Americanos, 12(1), 101-126. https://doi. org/10.4067/S0719-09482012000100005

Hernández,A. (2016). El currículo en contextos deestudiantes migrantes: Las complejidades del desarrollo curricular desde la perspectiva de los docentes de aula. Estudios Pedagógicos, 42(2), 151-169. https://doi.org/10.4067/S0718-07052016000200009

Horenczyk, G., \& Tatar, M. (2002). Teachers' attitudes toward multiculturalism and their perceptions of the school 
organizational culture. Teaching and Teacher Education, 18(4), 435-445. https://doi.org/10.1016/S0742-051X(02)00008-2 InstitutoNacionaldeEstadísticas(2020). Estimacióndepersonasextranjeras residentes habituales en Chile al 31 de diciembre 2019. Santiago de Chile: INE. Retrieved from: https://www.ine.cl/docs/defaultsource/demografia-y-migracion/publicaciones-y-anuarios/ migraci $\% \mathrm{C} 3 \% \mathrm{~B} 3 \mathrm{n}$-internacional/estimaci $\% \mathrm{C} 3 \% \mathrm{~B} 3 \mathrm{n}$ poblaci \% C 3\%B 3 n-extranjera-en-chile-2018/ estimaci $\% \mathrm{C} 3 \% \mathrm{~B} 3 n$-poblaci\%C3\%B3n-extranjera-en-chile2019-metodolog\%C3\%ADa.pdf?sfvrsn=5b145256_6

Instituto Nacional de Estadísticas (2018). Resultados Censo 2017. Retrieved from: https://redatamine.ine.cl/redbin/ RpWebEngine.exe/Portal?BASE=CENSO_2017\&lang=esp

Jiménez, F., \& Fardella, C. (2015). Diversidad y rol de la escuela. Discursos del profesorado: en contextos educativos multiculturales en clave migratoria. Revista Mexicana de Investigación Educativa, 20(65), 419-441.

Joiko, S. \& Vásquez, A. (2016). Acceso y elección escolar de familias migrantes en Chile: No tuve problemas porque la escuela es abierta, porque acepta muchas nacionalidades. Calidad en la Educación, 2(45), 132-173. https://doi.org/10.4067/ S0718-45652016000200005

Kao, G. \& Thompson, J. S. (2003). Racial and Ethnic Stratification in Educational Achievement and Attainment. Annual Review of Sociology, 29, 417-442. https://doi.org/10.1146/annurev. soc. 29.010202 .100019

Keltner, D., \& Haidt, J. (1999). Social Functions of Emotions at Four Levels of Analysis. Cognition \& Emotion, 13(5), 505-521. https://doi.org/10.1080/026999399379168

Kemper, T. D. (1984). Power, status, and emotions: A sociological contribution to a psychophysiological domain. In: Ekman, P., \& Scherer, K. R. (Eds.). Approaches to emotion (pp. 377-378). USA: Erlbaum Associates. 
León del Barco, B. L.; Mira, A. R. \& Gómez, T. (2007). Evaluación de las opiniones sobre la inmigración y la multiculturalidad en la escuela de alumnos de Magisterio. Revista Electrónica de Investigación Psicoeducativa, 12, 5(2), 259-282. https://doi. org/10.25115/ejrep.v5i12.1271

Mera, M.J., Martínez-Zelaya, G., Bilbao, MA. \& Garrido, A. (2017). Chilenos ante la inmigración: un estudio de las relaciones entre orientaciones de aculturación, percepción de amenaza y bienestar social en el Gran Concepción. Universitas Psychologica, 16(5), 1-14. https://doi.org/10.11144/Javeriana.upsy16-5.cier

Ministerio de Educación de Chile (2018). Estadisticas de la Educación 2017. Publicación diciembre 2018. Santiago de Chile: Centro de Estudios MINEDUC.

Montreuil, A., Bourhis, R., \& Vanbeselaere, N. (2004). Perceived Threat and Host Community Acculturation Orientations toward Immigrants: Comparing Flemings in Belgium and Francophones in Quebec. Canadian Ethnic Studies, 36(3), 113-135.

Navas, L., Holgado, F. P., \& Sánchez, A. (2009). Predicción de los estereotipos académicos ante los estudiantes inmigrantes. Horizontes educacionales, 14(2).

Navas, L. \& Sánchez, A. (2010). Actitudes de los Estudiantes de Pedagogía de las Regiones del Bío Bío y la Araucanía de Chile hacia la Presencia de Niños Inmigrantes en la Escuela: Análisis Diferenciales. Psykhe, 19(1), 47-60. https://doi.org/10.4067/ S0718-22282010000100004

Navas, M., \& Rojas, A. J. (2010). Aplicación del Modelo Ampliado de Aculturación Relativa (MAAR) a nuevos colectivos de inmigrantes en Andalucía: ecuatorianos y rumanos. Sevilla: Junta de Andalucía, Consejería de Empleo.

Pajares, F. (2007) Culturalizing educational psychology. In F. Salili \& R. Hoosain (Eds.). Culture, motivation and learning: $A$ multiculturalperspective (pp. 19-42). Charlotte, NC: Information Age Publishing. 
Pavez, I. (2012) Inmigración y racismo: experiencias de la niñez peruana en Santiago de Chile. Si Somos Americanos, 12(1), 75-99. https://doi.org/10.4067/S0719-09482012000100004

Riedemann, A., \& Stefoni, C. (2015). Sobre el racismo, su negación, y las consecuencias para una educación anti-racista en la enseñanza secundaria chilena. Polis, 14(42), 191-216. https:// doi.org/10.4067/S0718-65682015000300010

Salas, N., Castillo, D., San Martín, C., Kong, F., Thayer, L.E., \& Huepe, D. (2017) Inmigración en la escuela: caracterización del prejuicio hacia escolares migrantes en Chile. Universitas Psychologica, 16(5), 1-15. https://doi.org/10.11144/Javeriana. upsy16-5.iecp

Siqués, C., Vila, I. \& Perera, S. (2009). Percepciones y actitudes del alumnado extranjero y del profesorado: un estudio empírico en las aulas de acogida de Cataluña. Electronic Journal of Research in Educational Psychology, 17, 7 (1), 103-132. https://doi. org/10.25115/ejrep.v7i17.1312

Sirlopú, D., \& Van Oudenhoven, J. P. (2013). Is multiculturalism a viable path in Chile? Intergroup and acculturative perspectives on Chilean society and Peruvian immigrants. International Journal of Intercultural Relations, 37(6), 739-749. https://doi. org/10.1016/j.ijintrel.2013.09.011

Spencer-Rodgers, J., \& McGovern, T. (2002). Attitudes toward the culturally different: The role of intercultural communication barriers, affective responses, consensual stereotypes, and perceived threat. International Journal of Intercultural Relations, 26(6), 609-631. https://doi.org/10.1016/S0147-1767(02)00038-X

Stephan, W., Renfro, C., Esses, V., Stephan, C., \& Martin, T. (2005). The effects of feeling threatened on attitudes toward immigrants. International Journal of Intercultural Relations, 29(1), 1-19. https://doi.org/10.1016/j.ijintrel.2005.04.011

Tajfel, H., \& Turner, J.C. (1979). An integrative theory of intergroup conflict. En W.G. Austin y S. Worchel (Eds.). The Social 
Psychology of intergroup relations (pp. 33-47). Monterey, CA: Brooks- Cole.

Thayer, L.E, Córdova, G., \& Ávalos, B. (2013). Los límites del reconocimiento: migrantes latinoamericanos en la Región Metropolitana de Santiago de Chile. Perfiles Latinoamericanos, 42, 163-191. https://doi.org/10.18504/pl2142-163-2013

Tijoux, M. E. (2013). Las escuelas de la inmigración en la ciudad de Santiago: Elementos para una educación contra el racismo. Polis, 12(35), 287-307. https://doi.org/10.4067/ S0718-65682013000200013

Tijoux, M. E., \& Palominos, S. (2015). Aproximaciones teóricas para el estudio de procesos de racialización y sexualización en los fenómenos migratorios de Chile. Polis, (42).

Tropp, L. R., \&Pettigrew, T.F. (2005). Differential Relationships Between Intergroup Contact and Affective and Cognitive Dimensions of Prejudice. Personality and Social Psychology Bulletin, 31(8), 1145-1158. https://doi.org/10.1177/0146167205274854

Tyler, K. M., Boykin, A. W., \& Walton, T. R. (2006). Cultural considerations in teachers' perceptions of student classroom behavior and achievement. Teaching and Teacher Education, 22, 998-1005. https://doi.org/10.1016/j.tate.2006.04.017

Valenzuela, P., Riveros, K., Palomo, N., Araya, I., Campos, B., Salazar, C. \& Tavie, C. (2014). Integración laboral de los inmigrantes haitianos, dominicanos y colombianos en Santiago de Chile. Revista Antropologías del Sur, 2, 101-120.

Vecina, C. (2006). La violencia simbólica en la interacción entre docentes y alumnos inmigrantes. Revista Aposta de Ciencias Sociales, 24, 1-17.

Vedder, P., Wenink, E., \& van Geel, M. (2016). Explaining negative outgroup attitudes between native Dutch and Muslim youth in The Netherlands using the Integrated Threat Theory. International Journal of Intercultural Relations, 53, 54-64. https:// doi.org/10.1016/j.ijintrel.2016.05.001 
Velasco, K., Verkuyten, M., Weesie, J., \& Poppe, E. (2008). Prejudice towards Muslims in the Netherlands: Testing integrated threat theory. British Journal of Social Psychology, 47(4), 667-685. https://doi.org/10.1348/014466608X284443

Verkuyten, M. \& Thijs, J. (2002) School Satisfaction of Elementary School Children: The Role of Performance, Peer Relations, Ethnicity and Gender. Social Indicators Research, 59, 203-228. https://doi.org/10.1023/A:1016279602893

Ward, C., \& Masgoret, A. M. (2008). Attitudes toward immigrants, immigration, and multiculturalism in New Zealand: A social psychological analysis. International Migration Review, 42(1), 227-248. https://doi.org/10.1111/j.1747-7379.2007.00119.x

Wong, C., Eccles, J. \& Sameroff, A. (2003) The Influence of Ethnic Discrimination and Ethnic Identification on African American Adolescents' School and Socioemotional Adjustment. Journal of Personality, 71(6), 1198-123. https://doi. org/10.1111/1467-6494.7106012

Yzerbyt, V., \& Demoulin, S. (2010). Intergroup Relations. Handbook of Social Psychology. https://doi.org/10.1002/9780470561119. socpsy002028 


\section{Apendix}

Items of Attitude to Multiculturality at School Scale. Spanish version

1.- Una escuela multicultural sería buena

2.- Todos los alumnos inmigrantes tienen derecho a una educación

3.- La variedad étnica en las escuelas supone una experiencia positiva y enriquecedora

4.- La presencia de alumnos inmigrantes en la escuela influye negativamente en el rendimiento del grupo.

5.- La presencia de alumnos inmigrantes en un centro escolar afecta negativamente el prestigio del centro.

6.- Los alumnos inmigrantes están peor preparados que los autóctonos. 7.- La presencia de alumnos inmigrantes en la escuela dificulta el desarrollo de actividades en el aula.

8.- Tener alumnos inmigrantes es un serio problema para los centros educativos.

Recibido: 20/11/2019

Revisado: 12/06/2020

Aceptado: 01/07/2020 